\title{
Anti-nutritional factors and digestibility of protein in Cayocar brasiliense seeds
}

\author{
Virgínia Campos SILVESTRINI ${ }^{1}$, Daniel Bonoto GONÇALVES ${ }^{1}$, Paulo Afonso GRANJEIRO ${ }^{1}$, José Antonio da SILVA ${ }^{1 *}$
}

\begin{abstract}
The Brazilian Cerrado presents a wide variety of natural products, including the Pequi (Caryocar brasiliense). The important factor that determines the dietary and nutritional ideality of protein is degestitibility. This work aims to evaluate the protein digestibility of Pequi seeds and the presence of anti-nutritional factors. The protein Pequi almonds were extracted, toasted and untoasted. Evaluation digestibility was structurally characterized by SDS-PAGE 15\%, which can be used to analyze simulated gastric fluid (SFG) and digestion in intestinal fluid (SFI) in the presence of pepsin and trypsin/chymotrypsin. The extract from Pequi almonds showed inhibitory activity and was not detected hemagglutination. The intensity of the bands according to $2 \mathrm{~S}$ albumins, after heat treatment, did not decrease in comparison to the condition native, significantly. In the crisp crude extract, which was incubated under SGF and SIF, the intensity of the corresponding bands at 8 and $3 \mathrm{kDa}$ was resistant to SGF and indigestible after 4 hours under SIF. The characterization of Pequi almonds demonstrated that the product of the crude extract has anti-nutritional factors, which were confirmed by evaluating digestibility.
\end{abstract}

Keywords: Caryocar brasiliense; almonds; in vitro digestibility; $2 \mathrm{~S}$ albumin; peptidase inhibitor; lectins.

Practical Application: The study of anti-nutritional factors identification is very important because of its inactivation on food industry and it can also be used to avoid allergy due to them.

\section{Introduction}

Animal and vegetable proteins obtained from food are very important source of amino acids, especially the essentials. It is clear that is necessary to multiply the offering of proteins while there is a fast increase in the world population. Those from the vegetal origins have an important significance because it is indispensable food source in development countries (World Health Organization, 2007).

Pequi is one of the native species of the Cerrado, widely used by the population because of its high nutritional value, variety of nutrients and especially socioeconomic value (Kerr et al., 2007; Pinto et al., 2009; Baeta, 2013). The fruit is formed by almonds and hoopoes, in which the first is responsible for the extraction of proteins. The presence of proteins in almond can be related to the source of plant reserves may have from 10 to $40 \%$ by dry weight, as it should be necessary to ensure that the protein reserves for the plant development stages (Lima et al., 2007; Costa, 2012).

Protein source has important nutritional value when there are adequate compositions in terms of total amino acids, essential amino acids, digestibility, method of preparation, anti-nutritional factors and toxicity. Despite its nutritional availability, as a product of plant origin, Pequi can have anti-nutritional properties, synthesized by the fruits, for their own defense. Thus the diet and nutritional quality of the protein could be defined by digestibility (Pompeu et al., 2014; Silva et al., 2015a; Maradini-Filho et al., 2017).
The anti-nutritional factors present in food may reduce the bioavailability of nutrients and also cause harmful effects to human health, for example lectins, $2 S$ albumins and peptidase inhibitors. Some plants kernels have proteins associated with the defense mechanism against insects and microorganisms (Oliveira et al., 2014) and when these vegetables are eaten, these proteins are considered toxic and antinutritional (Gonçalves et al., 2016).

Peptidase inhibitors are endemic diffused in vegetables and is able to inhibit some enzymes, among which trypsin and chymotrypsin (Oliva et al., 2011; Silva et al., 2015a, b; Pesoti et al., 2015; Pompeu et al., 2016). The adverse health effects have been detected in experimental animals and it can be seen that occurred pancreatic hypertrophy, decreased growth and weight reduction in animals (Grela, 1996; Clemente et al., 2015).

Lectins can act as non-nutritional factors with the capacity to combine with sugars and glycoconjugates, inducing erythrocyte agglutination (Silva et al., 2007; Van Damme, 2014). The consumption of power by lectins, can lead to gross changes of various animal organs and even lead to hyperplasia and hypertrophy of the pancreas and intestine and may lead to various adverse health effects, by decreasing the absorption of nutrients (Seena \& Sridhar, 2004; Pompeu et al., 2015). This is because lectin glycosylated binds to receptors present on intestinal cells and thus interferes with the processes of digestion, absorption and utilization of nutrients (Vasconcelos \& Oliveira, 2004). 
2S Albumins may differ in chains, but converge on features to be structurally homologous, they are classified as compact globular proteins with arrangement and distribution of conserved disulfide bridges. $2 \mathrm{~S}$ albumins Isoforms are composed by two disulfide bonds linked a large subunit $(9 \mathrm{kDa})$ and a small subunit (3-4 kDa) (Shewry et al., 1995; Pantoja-Uceda et al., 2003; Koppelman et al., 2005; Hsiao et al., 2006; Lule et al., 2015). Moreover, this class of protein showed a broad spectrum function that has been described as a new trypsin inhibitor (Mandal et al., 2002). Additionally, the immune system is sensible to the most food allergens that are stable and have the capacity to reach the intestinal mucosa and than release an IgE-mediated allergic response (Dimitrijevic et al., 2010; Kumar et al., 2014; De Angelis et al., 2017).

The SDS-PAGE technique has been generally used to conduct the analysis of the gastric fluid (SFG), in the presence of pepsin, and the intestinal fluid (SFI) in the presence of trypsin/chymotrypsin. In addition, in vitro digestibility of protein after heat treatment can be measured, probably due to denaturation of peptidase inhibitors, $2 \mathrm{~S}$ albumins and lectins, inactivating the antinutritional factors (Pompeu et al., 2014; Lang et al., 2015; Silva et al., 2015a).

One of the consequences of low level of digestibility is the hydrogen bonding, hydrophobic interactions and disulfide bonds that stabilized the variety of globular structures of food proteins. The role of anti-nutritional factors in food is little known in Caryocaraceae family, and in addition to the need for knowledge of suitable methods for the inactivation of these in the food industry, the study to evaluate the influence on digestibility of proteins and amino acids availability is required (Damiani et al., 2013).

This study aims to evaluate the protein digestibility of seeds Pequi (Caryocar brasiliense) to determine the presence of peptidase inhibitor, $2 \mathrm{~S}$ albumin and lectin using Osborne method and heat treatment to simulate digestion.

\section{Materials and methods}

\subsection{Chemicals}

Bovine serum albumin (BSA), bovine pancreatic trypsin, a-chymotrypsin and bovine pancreatic, NR-benzoyl-DL-argininep-nitroanilide (BApNA) and N-benzoyl-L-tyrosine p-nitroanilide (BTpNA) were purchased from Sigma (St. Louis, MO, USA) and acrylamide, bis-acrylamide, dithiothreitol (DTT), standard molecular weight marker and other electrophoresis reagents. The seeds of Caryocar brasiliense were collected at the Federal University of São João del Rei (UFSJ).

\subsection{Protein extraction}

The crude extract was obtained according to the method of Osborne (Osborne, 1924), which toasted and untoasted seeds $(50 \mathrm{~g})$ were ground using a power mill by stirring with $1 \mathrm{mM}$ phosphate buffer $\mathrm{pH} 7.6$ for $1 \mathrm{~h}$ at $37^{\circ} \mathrm{C}$. After the crude extract was centrifuged at $3.600 \mathrm{xg}$ for $15 \mathrm{~min}$ at $37^{\circ} \mathrm{C}$, using distilled water to dialysis for $48 \mathrm{~h}$ at $4{ }^{\circ} \mathrm{C}$ and then lyophilized.

\subsection{Determination of protein concentration}

The protein assay was determined using the Bradford method (Bradford, 1976), assuming that an $\mathrm{A}_{760}$ of 1.0 corresponded to a protein concentration of $1 \mathrm{mg} / \mathrm{mL}$ using BSA as standard.

\subsection{Peptide inhibition assays}

The trypsin inhibitor activity assay used $50 \mathrm{~mL}$ of crude extract $(1 \mathrm{mg} / \mathrm{mL})$ incubated with $50 \mathrm{~mL}$ of trypsin $(0.33 \mathrm{mg} / \mathrm{mL}$ of $1 \mathrm{mM} \mathrm{HCl}$ ) and $250 \mu \mathrm{L}$ of $0.1 \mathrm{M}$ of Tris- $\mathrm{HCl}$ buffer $\mathrm{pH} 8.0$, during $10 \mathrm{~min}$ at $37^{\circ} \mathrm{C}$. After, $1.0 \mathrm{~mL}$ of BAPNA solution (0.4 mg/mL BAPNA 0.1 M Tris-HCl buffer $\mathrm{pH} 8.0$ ) was mixed and incubated for $20 \mathrm{~min}$ at $37^{\circ} \mathrm{C}$. The reaction was stopped with $500 \mu \mathrm{L}$ of $30 \%$ acetic acid solution according to Cruz et al. (2013). The amount of inhibitor required for $50 \%$ inhibition by trypsin using BAPNA as the substrate was defined as one unit. This experiment was performed in triplicate and the results were plotted as mean \pm standard deviation (SD).

\subsection{Hemaggutionation assay}

The Pequi extract was subjected to a hemagglutination assay, as proposed by Pompeu et al. (2015). These trials were conducted using B and $\mathrm{O}$ human bloods in the presence and absence of trypsin in 96-well plate. To characterize the minimal concentration able to erythrocytes of different types $15 \mathrm{mg} / \mathrm{mL}$ of crude extract was diluted in series in the 96-well plate. These assays were performed in the presence of EDTA in CTBS solution $\left(150 \mathrm{mM} \mathrm{NaCl}, 20 \mathrm{mM}\right.$ Tris- $\left.\mathrm{HCl}, 5 \mathrm{mM} \mathrm{CaCl}_{2}\right)$. The experiment was performed in triplicate.

\subsection{Electrophoresis}

The apparent molecular weight was estimated using DTT (Ditiotreitol) for reducing conditions (15\% SDS-PAGE) using Bio Rad electrophoresis system (Hercules/USA) according to Laemmli (1970). The amount of $50 \mathrm{mg} / \mathrm{mL}$ of crude extract was added to $10 \mu \mathrm{L}$ of sample buffer and $0.1 \%$ Coomassie R-250 bright blue was used to staining proteins.

\subsection{Analysis of in vitro digestibility}

Three different peptidases: trypsin (E.C. 3.4.21.4, Type III), a-chymotrypsin (E.C. 3.4.21.1, Type II) and Pepsin A (E.C. 3.4.23.1) were used to perform the in vitro digestibility using SDS-PAGE. The enzymes were used to simulate gastric fluid (SGF) and intestinal fluid (SIF). The seeds were evaluated under native conditions, thermal denatured $\left(100^{\circ} \mathrm{C}\right.$ for $\left.30 \mathrm{~min}\right)$ and toasted $\left(120^{\circ} \mathrm{C}\right.$ for $30 \mathrm{~min})$. In SGF $40 \mu \mathrm{L}$ of the crude extract fraction $(24 \mathrm{mg} / \mathrm{mL}$ of crude extract diluted in $250 \mu \mathrm{L}$ of $10 \mathrm{mM}$ phosphate buffer $\mathrm{pH} 6.8)$ was mixed with $5 \mu \mathrm{L}$ of enzyme $(6.2 \mathrm{mg} / \mathrm{mL}$ pepsin, $50 \mathrm{mM} \mathrm{HCl}$ and $0.1 \mathrm{M}$ phosphate buffer containing $0.1 \mathrm{M} \mathrm{NaCl}$ $\mathrm{pH} 7.7)$ and $55 \mu \mathrm{L}$ sample buffer. In SIF $40 \mu \mathrm{L}$ of the crude extract fraction $(24 \mathrm{mg} / \mathrm{mL}$ of crude extract diluted in $250 \mu \mathrm{L}$ of $0.1 \mathrm{M}$ phosphate buffer with $\mathrm{NaCl} \mathrm{pH} \mathrm{7.7)} \mathrm{was} \mathrm{mixed} \mathrm{with} 5 \mu \mathrm{L}$ of enzyme $(1 \mathrm{mg} / \mathrm{mL}$ of trypsin/chymotrypsin in $0.1 \mathrm{M}$ phosphate buffer with $\mathrm{NaCl} \mathrm{pH} \mathrm{7.7)} \mathrm{and} \mathrm{sample} \mathrm{buffer.} \mathrm{After,} 15 \mu \mathrm{L}$ of the mixed sample was added in different times $0.5,1,2,4$ and $8 \mathrm{~h}$ according the condition SGF or SIF. 


\subsection{Statistical analysis}

A comparison of mean residual trypsin activity was performed by ANOVA one way $(\alpha=0.05)$, followed by the Tukey test with $5 \%$ confidence limits.

\section{Results and discussion}

\subsection{Hemagglutination activity detection and inhibitory for Protease}

In non-leguminous plants of almonds there are some studies that have detected the presence of peptidase inhibitors or hemagglutinating activities. The protein content in the studied Caryocar brasiliense species of seeds is shown in Table 1. However, this had low protein content and a lower percentage of the residual activity of trypsin, indicating potentially lower enzyme inhibition (Figure 1).

For detection of hemagglutination activity (AHE) in the total extract of the species under study, they used red blood cells from all blood types, in order to select the one with greater susceptibility to hemagglutination. However, for the C. brasiliense extracts AHE not detected over the tested erythrocytes.

As the AHE is the best known property of lectins, this is the most widely used method for the detection of these proteins. The results showed the specificity of lectins in the two tests made with different concentrations, one test done with $4 \mathrm{mg} / \mathrm{mL}$ and another made with $8 \mathrm{mg} / \mathrm{ml}$, since the hemagglutinating effect

Table 1. Concentration of protein in protein extracts from roasted and untoasted Pequi seeds.

\begin{tabular}{lc}
\hline \multicolumn{1}{c}{ Sample } & $\mathrm{mg}$ proteins $/ \mathrm{mL}$ \\
\hline Caryocar brasiliense toasted & 0.088 \\
Caryocar brasiliense untoasted & 0.167 \\
\hline
\end{tabular}

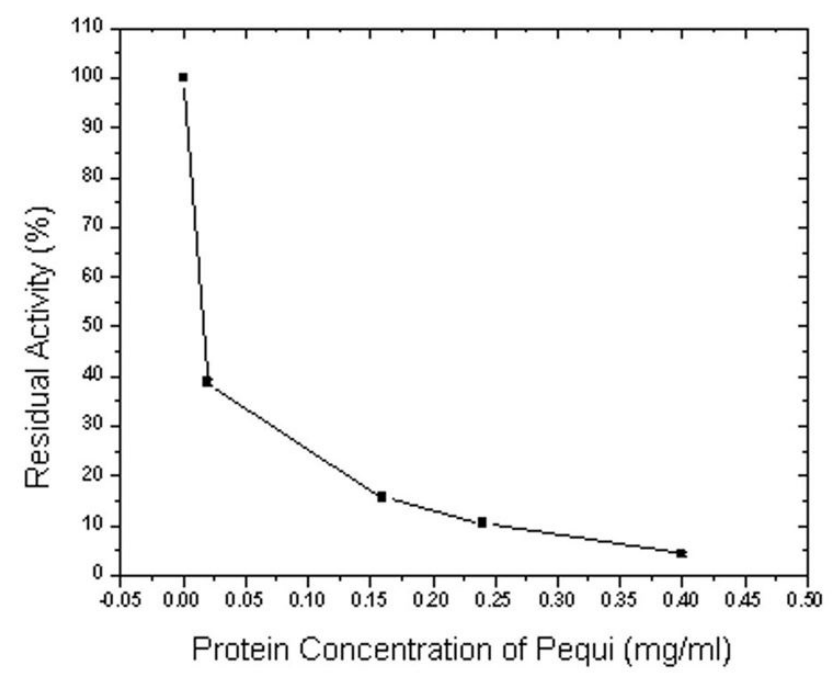

Figure 1. Inhibition of trypsin activity by the crude protein extract of C. brasiliense seeds. Hydrolysis of BAPNA by $1 \mathrm{mM}$ bovine trypsin at $\mathrm{pH} 8.0$ at $37^{\circ} \mathrm{C}$, in the presence of increasing concentrations of total extract protein. caused by these proteins is dependent on the molecular structure of each lectin individually.

Pequi seed extract demonstrated trypsin inhibitory activity. An inhibition curve was performed using the Pequi extract and trypsin showed that lost 60 and $76 \%$ of its activity when the molar ratio was 0.05 and $0.1 \mathrm{mg} / \mathrm{mL}$, respectivelly. Proportionally, the $2 \mathrm{~S}$ albumin Pequi inhibited the same mass of bovine trypsin using the specific substrate, BApNA. Other result presented the same values according to trypsin inhibitor belongs to Kunitz family, such as SKTI from soy seeds (Ribeiro, 2010).

The harms of anti-nutritionals factors such as peptidase inhibitors are reported in animal studies, and observed pancreatic hypertrophy, and some lectins may have toxicity and not others (Pompeu et al., 2014). Lima et al. (2008) found a trypsin inhibitor in jabuticabas, with higher levels observed in seeds, followed by the peel and the entire fruit, with lower levels in the pulp and hemagglutination activity in the peel. Peptidase inhibitors and lectin were observed in almonds bacuri and seeds sapucaia (Barbosa, 2006; Denadai et al., 2007), while Hiane et al. (2006) detected low concentrations of lectins and no peptidase inhibitors in bocaiuva almonds.

\subsection{Electrophoresis of isolated fractions of Pequi seeds}

There are a few studies about the digestibility of proteins in Caryocaceae family. Pequi seeds were used without toasting, it native or denatured being, and toast for the preparation of protein digestibility in vitro. Electrophoresis on polyacrylamide gel was performed to determine the molecular weight and number of protein bands, which is an easy method to implement and low cost (Anema, 2009). Figure 2 shows the amount of protein extracted without heating and roasted crude extract from the delipidated flour $15 \mathrm{~g}$, half of which was used for roast extract and the other half to extract untoasted. The electrophoretic pattern of protein extracts, not roasted and toasted, the species studied showed seeds distribution of protein bands between the molecular weight ranges from about 110 to $3 \mathrm{kDas}$.

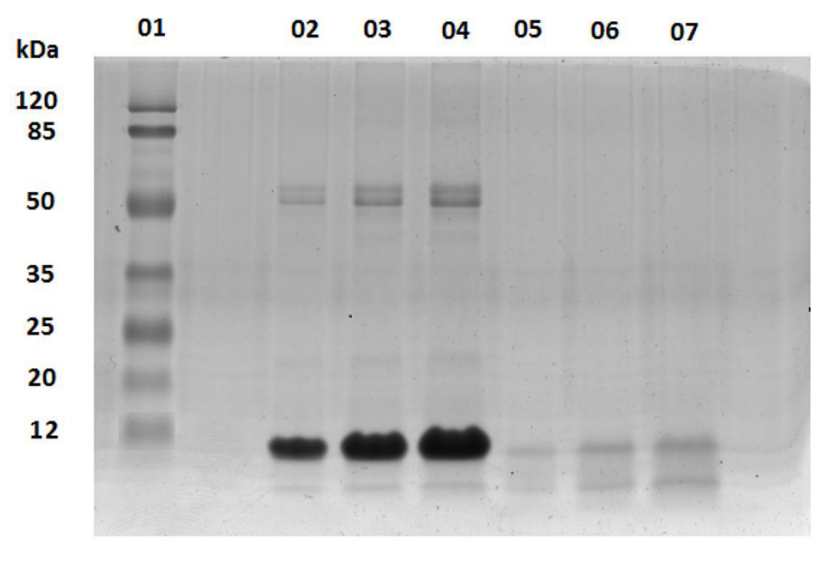

Figure 2. Electrophoretic profile of Pequi protein fractions in $15 \%$ SDS-PAGE. Column 1: molecular weight marker; Columns 2, 3 and 4: extract of untoasted at concentrations 0.006 to $0.018 \mathrm{mg}$; Columns 5,6 and 7 : toasted extract at concentrations of 0.006 to $0.018 \mathrm{mg}$. 
For almond Pequi without toasting, it was observed that the protein content showed bands of 110,52 and $51 \mathrm{kDa}$ and other minors between 23.11 and $3 \mathrm{kDa}$. Regarding almonds were subjected to roasting processes it was observed in the electrophoretic profile of proteins, the presence of two strong protein bands with molecular weight of 8 and $3 \mathrm{kDa}$.

In a study by Hiane et al. (2006), it was observed that the globulin protein bocaiuva almond showed three bands, one above $100 \mathrm{kDa}, 66 \mathrm{kDa}$ and another of $60 \mathrm{kDa}$. In almond sapucaia, Denadai et al. (2007) identified the bands for globulin for $18,34,40$ and $50 \mathrm{kDa}$. When some bands were disappeared toast, this fact can probably be attributed to the reactions occurring during the roasting process, such as Maillard complexation with polyphenolic compounds in addition to the possible formation of different polymers. These various reactions that occur during roasting can produce insolubilization and lower extractability of the protein during preparation of the sample to be applied on the gel. The roasted seeds contained low protein quality, which is probably due to its amino acid profile (Freitas \& Naves, 2010).

It not was found on the gel electrophoresis SDS-PAGE molecular mass protein Pequi between 30 and $35 \mathrm{kDa}$ that is typical of the structure of lectins (Sharon \& Lis, 1995; Devi et al., 2014; Van Damme, 2014). Technically, the protein bands present in the range of 5-25 kDa suggest the presence of inhibitors of serine peptidases type Kunitz, Bowman-Birk and $2 S$ albumin which has been reported in the scientific literature (Carlini \& Grossi-de-Sá, 2002; Ruan et al., 2011). The band near the molecular weight of $11 \mathrm{kD}$ as was more abundant in both phases, this being apparently very similar to the protein that shows $40 \%$ activity against trypsin, purified from Pequi seed, called 2S albumin (Costa, 2012).

\subsection{Seeds of crude extract untoasted simulating gastric fluid (SGF)}

In the Figure $3 \mathrm{~A}$ the pepsin was incubated with the sample of the crude extract. Bands of proteins at 110, 52, 51, 23 and $11 \mathrm{kDa}$ was observed at various times up to 8 hours under the condition of
SGF (simulated fluid gastric) in 15\% SDS-PAGE. Furthermore, no hydrolysis products were detected. Subsequently denaturation treatment, pepsin easily degrades bands of proteins at 110,52 and $23 \mathrm{kDa}$, but one $11 \mathrm{kDa}$ band was resistant and divided into two subassemblies 8 and $3 \mathrm{kDa}$ (Figure $3 \mathrm{~B}$ ).

\subsection{Seeds of crude extract untoasted simulating intestinal fluid (SIF)}

In the Figure $4 \mathrm{~A}$ the trypsin/chymotrypsin were incubated with the sample of the crude extract. Bands of proteins at 52 and $51 \mathrm{kDa}$ gradually decreased under the condition of SIF, but 120 and $11 \mathrm{kDa}$ bands were resistant in 15\% SDS-PAGE. Furthermore, there hydrolysis products in the range 50 to $20 \mathrm{kDa}$. After thermal treatment, the band according to $11 \mathrm{kDa}$ (2S Albumin) was not reduced significantly in comparison to native conditions (no heat treatment).

In this study, it was shown that the potential of the allergenic $2 \mathrm{~S}$ albumin after SGF and SIF digestion was not reduced significantly when compared with other Pequi proteins, which were digested. In addition, some studies have been demonstrated that digestibility is greatly influenced by $\mathrm{pH}$ level and temperature. Some rice proteins in SGF conditions were digested faster at $\mathrm{pH} 1.2$ as compared to $\mathrm{pH}$ levels of 2.0 and 2.5 as well as the effects of temperature were decisive in accelerating protein digestion (Pompeu et al., 2014; Gámez et al., 2015; He et al., 2015.; Lang et al., 2015).

\subsection{Seed extract toasted simulating gastric and intestinal fluid}

In the Figure 5A the crude extract sample was toasted, simulating the time to prepare the seed for consumption, and incubated with pepsin. In this condition no more bands of proteins are presented in the gel higher than $20 \mathrm{kDa}$ in comparison with untoasted. The presence of bands around 3 and $8 \mathrm{kDa}$ demonstrated that there are some proteins resistant to these enzymes up to $8 \mathrm{~h}$. In the Figure $5 \mathrm{~B}$ the crude extract sample was crisp and incubated with trypsin/chymotrypsin. In this condition

\section{B}

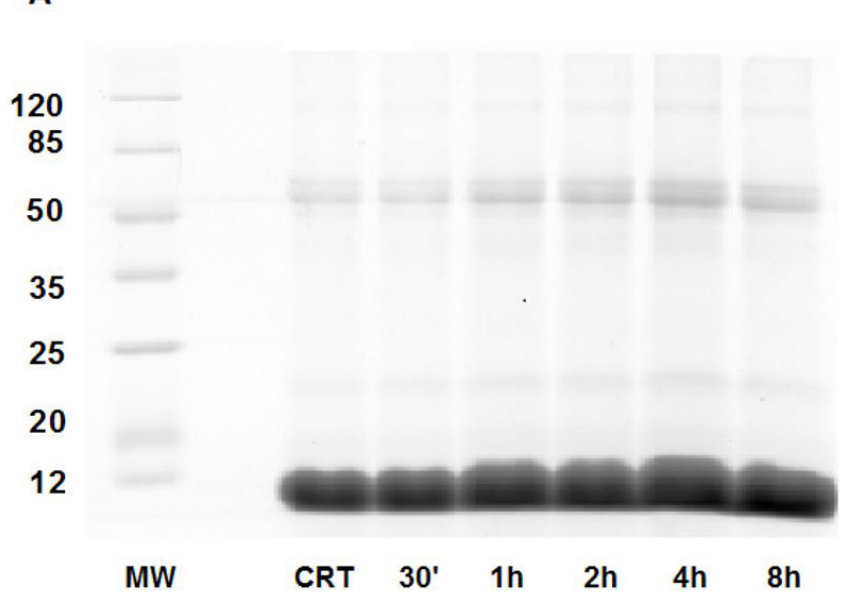

120
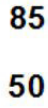

35

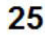

20

12

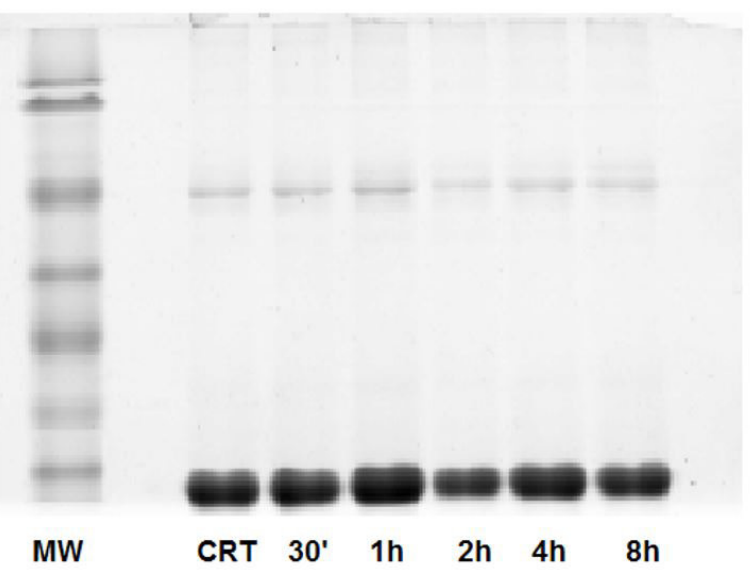

Figure 3. Electrophoretic profile of protein digestibility seed Pequi by Pepsin. (MW) molecular weight marker; time of incubation: 30 min to $8 \mathrm{~h}$; (CRT) control; Gel A: native. Gel B: denatured. 
A

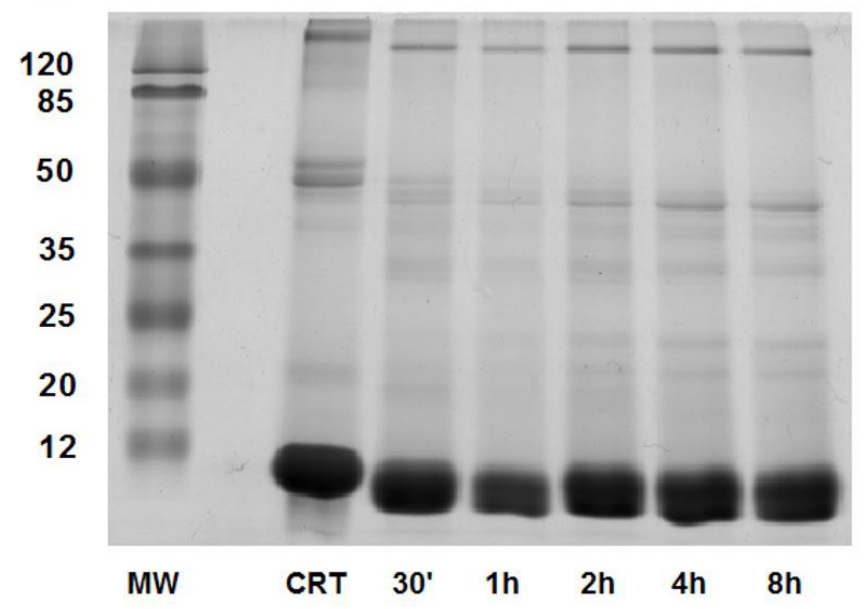

B

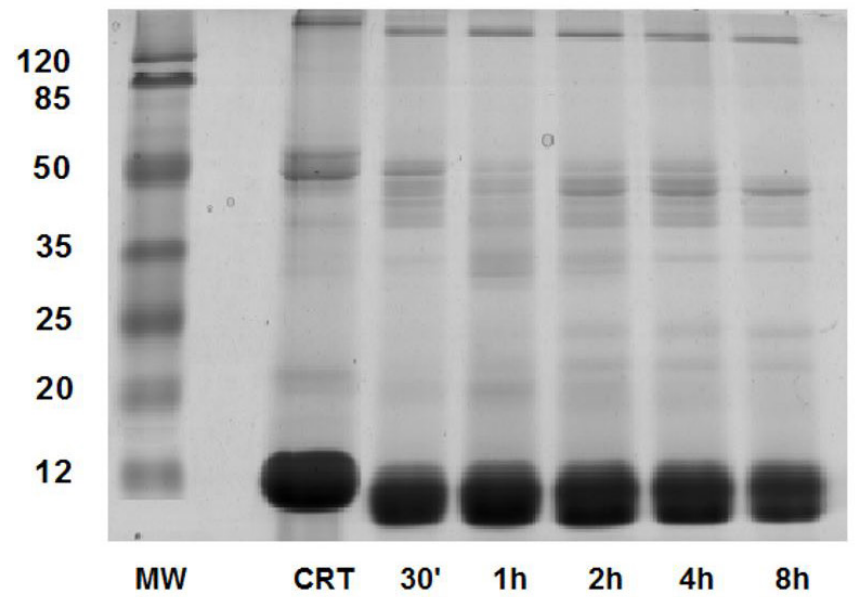

Figure 4. Electrophoretic profile of protein digestibility Pequi seed Trypsin/Chymotrypsin. (MW) molecular weight marker; time of incubation: 30 min to 8 h; (CRT) control; Gel A: native. Gel B: denatured.

A

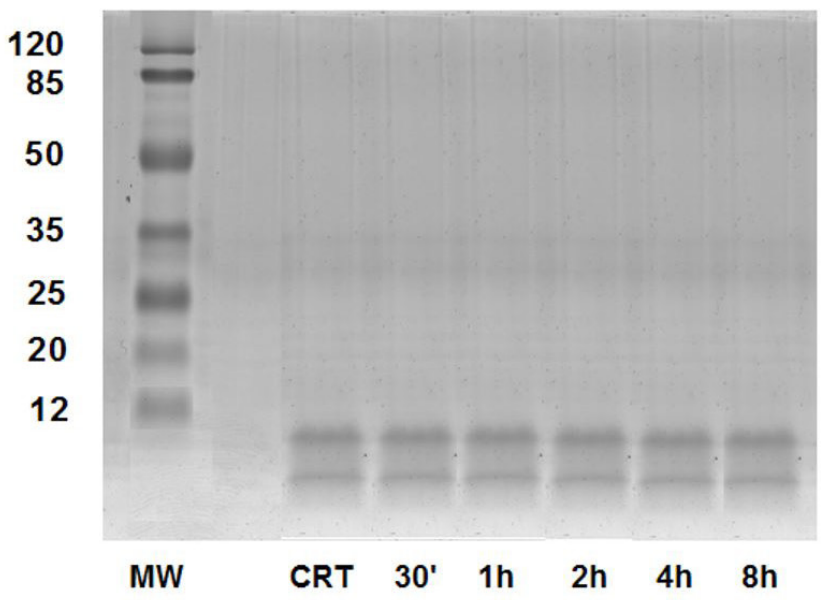

B

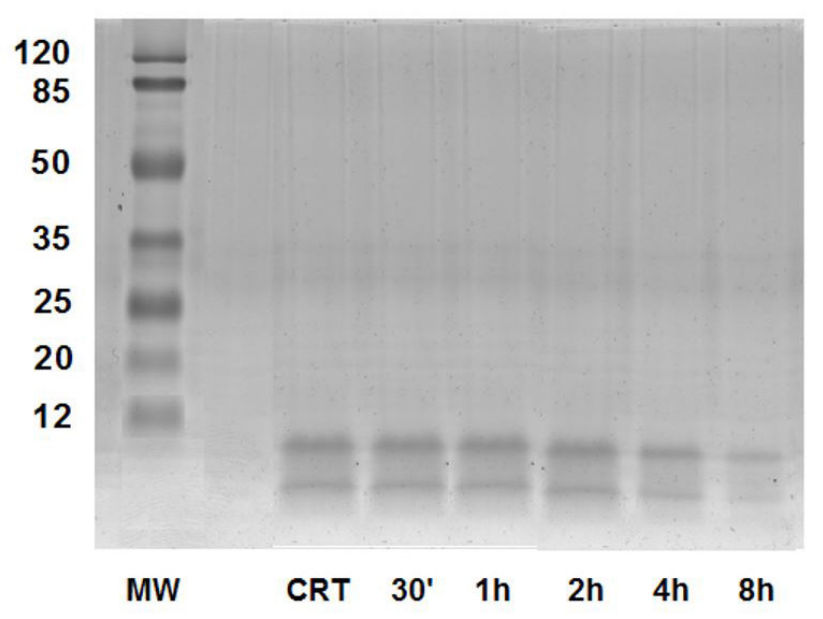

Figure 5. Electrophoretic pattern of protein digestibility in toasted Pequi seeds by pepsin (A) and trypsin/chymotrypsin (B). (MW) molecular weight marker; time of incubation: $30 \mathrm{~min}$ to $8 \mathrm{~h}$; (CRT) control; Gel A: native. Gel B: denatured.

no more bands of proteins are presented in the gel higher than $20 \mathrm{kDa}$ in comparison with untoasted. The presence of bands around 3 and $8 \mathrm{kDa}$ demonstrated that there are some proteins resistant to these enzymes up to $4 \mathrm{~h}$. The visual analysis of the gels indicated that thermal treatment proteins in the gastric conditions have higher resistance to proteolysis than in intestinal conditions, showing different stabilities related to food allergens.

These resistant proteins have been reported as $2 \mathrm{~S}$ albumins and are related in various species, including peanut, mustard, Brazil nut, sesame seed and sunflower (Murtagh et al., 2003; Moreno et al., 2005; Vissers et al., 2011; Orruno \& Morgan, 2011; Sirvent et al., 2012; Berecz et al., 2013).

It is clear that cysteine residues, in particular their connections intra-chain disulfide, stabilize the three-dimensional structure of the protein independently of its action against the digestive enzymes. However, almost every food allergens have some resistance, which upon reaching the digestive tract in a fragment with immunogenic conformation can cause systemic reactions (Moreno et al., 2005).

The main chain polypeptide and digested fragments are formed by disulfide links, corresponding an undigested protein and stabilized by the interactions of the three-dimensional structure. The high temperatures reached during the roasting process were capable of breaking the disulfide bonds of the protein, by modifying its tertiary structure, presenting the cleavage sites for the action of proteolytic enzymes. This fact has a great correlation with the $2 \mathrm{~S}$ albumins which present highly stable protein structures thermal denaturation and to proteolysis due to its compact 3D structures stabilized by disulfide bridges. Thus, the digestibility of these proteins is quite important, and these are shown only in SIF digestible toasted extracts after the time of 4h (Murtagh et al., 2003; Vissers et al., 2011). 
The stability against the action of digestive enzymes pepsin and trypsin/chymotrypsin from the Pequi seed extract suggests a high concentration of cysteine in its structure, which may contribute to reduce its nutritional quality. The globular structure of $2 \mathrm{~S}$ albumin has been shown to be more resistant to the action of pepsin, preventing the action of this proteolytic enzyme on the peptide bonds adjacent to the amino acids Met, Leu and aromatics, whereas it was less resistant to the action of trypsin/chymotrypsin on the peptides bonds adjacent to amino acids Arg, Lys and aromatics (Fontana et al., 2004; Singh et al., 2014).

Studies using electrophoresis have shown that native black bean lectins were resistant to both gastric and intestinal digestion (He et al., 2015). On the other hand, whole-grain proteins showed different levels of digestibility in gastric digestion and were susceptible to rapid intestinal digestion (Lang et al., 2015). Alteration in protein structure is evident with heat treatment, independent if it is gastric or intestinal, indicating that the conformational structure plays a primordial role in its resistance to proteolytic degradation (He et al., 2015). During a $60 \mathrm{~min}$ reaction period most food allergens are stable under gastric conditions (Grozdanovic et al., 2014; He et al., 2015). However, there is no consensus on which of the conditions allergenic proteins are more susceptible to the action of proteolytic enzymes (Fu et al., 2002).

\section{Conclusions}

Pequi seeds characterization demonstrated that the product of the crude extract has anti-nutritional factors. The protein of approximately $11 \mathrm{kDa}$ (untoasted) and 8 and $3 \mathrm{kDa}$ (toasted) proved quite similar to the $2 \mathrm{~S}$ albumins, which are able to bind to intestinal receptors triggering an IgE-mediated allergic response. In toasted conditions the $2 \mathrm{~S}$ albumin was more stable in gastric conditions and its globular structure contributed for the resistance to action of proteolytic enzymes. The nutritional capacity of protein Caryocar brasiliense was evaluate, however the mechanism involved in the digestion of these proteins needs more attention, which is not yet well established.

\section{Acknowledgements}

Financial support was from Federal University of São João Del-Rei (UFSJ), the Minas Gerais Research Foundation (FAPEMIG) and The National Council for Scientific and Technological Development (CNPq).

\section{References}

Anema, S. G. (2009). The use of "lab-on-a-chip" microfluidic SDS-PAGE electrophoresis technology for the separation and quantification of milk proteins. International Dairy Journal, 19(4), 198-204. http:// dx.doi.org/10.1016/j.idairyj.2008.11.001.

Baeta, D. S. (2013). Avaliação de características físico-químicas e bioquímicas do Pequi (Caryocar brasiliense Camb.) em suas diversas formas de armazenamento (Tese de mestrado). Universidade Estadual Paulista, Araraquara.

Barbosa, M. C. (2006). Composição de aminoácidos e digestibilidade in vitro de proteínas de amêndoas de bacuri (Scheelea phalerata
Mart.), do estado de Mato Grosso do Sul (Dissertação de mestrado). Universidade Federal de Mato Grosso do Sul, Campo Grande.

Berecz, B., Clare Mills, E. N., Parádi, I., Láng, F., Támas, L., Shewry, P. R., \& Mackie, A. R. (2013). Stability of sunflower $2 S$ albumins and LTP to physiologically relevant in vitro gastrointestinal digestion. Food Chemistry, 138(4), 2374-2381. PMid:23497898. http://dx.doi. org/10.1016/j.foodchem.2012.12.034.

Bradford, M. M. (1976). A rapid and sensitive method for the quantitation of microgram quantities of proteins utilizing the principle of proteindye binding. Analytical Biochemistry, 72(1), 248-254. PMid:942051. http://dx.doi.org/10.1016/0003-2697(76)90527-3.

Carlini, C. R., \& Grossi-de-Sá, M. F. (2002). Plant toxic proteins with insecticidal properties. A review on their potentialities as bioinsecticides. Toxicon, 40(11), 1515-1539. PMid:12419503. http:// dx.doi.org/10.1016/S0041-0101(02)00240-4.

Clemente, A., Arques, M. C., Dalmais, M., Le Signor, C., Chinoy, C., Olias, R., Rayner, T., Isaac, P. G., Lawson, D. M., Bendahmane, A., \& Domoney, C. (2015). Eliminating anti-nutritional plant food proteins: the case of seed protease inhibitors in pea. PLoS One, 4(9), 1-24. http://dx.doi.org/10.1371/journal.pone.0134634.

Costa, T. G. (2012). Prospecção de extratos de plantas do bioma do cerrado com potencial biotecnológico e isolamento de albumina $2 S$ (Dissertação de mestrado). Universidade Católica de Brasília, Brasília.

Cruz, A. C. B., Massena, F. S., Migliolo, L., Macedo, L. L. P., Monteiro, N. K. V., Oliveira, A. S., Macedo, F. P., Uchoa, A. F., Grossi De Sá, M. F., Vasconcelos, I. M., Murad, A. M., Franco, O. L., \& Santos, E. A. (2013). Bioinsecticidal activity of a novel Kunitz trypsin inhibitor from Catanduva (Piptadenia moniliformis) seeds. Plant Physiology and Biochemistry, 70, 61-68. PMid:23770595. http:// dx.doi.org/10.1016/j.plaphy.2013.04.023.

Damiani, C., Almeida, T. L., \& Costa, N. V., Medeiros, N. X., Silva, A. G. M., Silva, F. A., Lage, M. E., \& Becker, F. S. (2013). Perfil de ácidos graxos e fatores antinutricionais de amêndoas de pequi crua e torrada. Pesquisa Agropecuária Tropical, 43(1), 71-78.

De Angelis, E., Pilolli, R., Bavaro, S. L., \& Monaci, L. (2017). Insight into the gastro-duodenal digestion resistance of soybean proteins and potential implications for residual immunogenicity. Food \& Function, 8(4), 1599-1610. PMid:28294226. http://dx.doi.org/10.1039/ C6FO01788F.

Denadai, S. M. S., Hiani, P. A., Marangoni, S., Baldasso, P. A., Miguel, A. M. R. O., \& Macedo, M. L. R. (2007). In vitro digestibilidade of globulins from sapucaia (Lecthin pisonis Camb) nuts by mammalian digestive proteinases. Ciência e Tecnologia de Alimentos, 27(3), 535543. http://dx.doi.org/10.1590/S0101-20612007000300018.

Devi, P. R., Kombiah, P., Sudhakar, G. L. R., \& Babu, C. (2014). Purification and characterization of a novel lectin from Geotrupes stercorarius. International Journal of Advanced Biotechnology and Research, 5(2), 157-162. http://dx.doi.org/10.1021/jf5046014.

Dimitrijevic, R., Jadranin, M., Burazer, S., Ostojic, S., \& Gavrovic-Jankulovic, M. (2010). Evaluation of the thermal stability and digestibility of heterologously produced banana lectin. Food Chemistry, 120(4), 1113-1118. http://dx.doi.org/10.1016/j.foodchem.2009.11.062.

Fontana, A., Laureto, P. P., Spolaore, B., Frare, E., Picotti, P., \& Zambonin, M. (2004). Probing protein structure by limited proteolysis. Acta Biochimica Polonica, 512(2), 299-321. PMid:15218531.

Freitas, B. F., \& Naves, M. M. V. (2010). Composição química de nozes e sementes comestíveis e sua relação com a nutrição e saúde. Revista de Nutrição, 23(2), 269-279. http://dx.doi.org/10.1590/S141552732010000200010 . 
Fu, T. J., Abbott, U. R., \& Hatzos, C. (2002). Digestibility of food allergens and nonallergenic proteins in simulated gastric fluid and simulated intestinal fluids-a comparative study. Journal of Agricultural and Food Chemistry, 50(24), 7154-7160. PMid:12428975. http://dx.doi. org/10.1021/jf020599h.

Gámez, C., Zafra, M. A., Sanz, V., Mazzeo, C., Ibáñez, M. A., Sastre, J., \& Pozo, V. D. (2015). Simulated gastrointestinal digestion reduces the allergic reactivity of shrimp extract proteins and tropomyosin. Food Chemistry, 173, 475-481. PMid:25466048. http://dx.doi. org/10.1016/j.foodchem.2014.10.063.

Gonçalves, A., Goufo, P., Barros, A., Domínguez-Perles, R., Trindade, H., Rosa, E. A., Ferreira, L., \& Rodrigues, M. (2016). Cowpea (Vigna unguiculata L. Walp) a renewed multipurpose crop for a more sustainable agri-food system. Nutritional advantages and constraints. Journal of the Science of Food and Agriculture, 96(9), 2941-2951. PMid:26804459. http://dx.doi.org/10.1002/jsfa.7644.

Grela, E. R. (1996). Nutrient composition and contente of antinutritional factors in spelt (Triiticum spelta L.) cultivars. Journal of the Science of Food and Agriculture, 71(3), 399-404. http://dx.doi.org/10.1002/ (SICI)1097-0010(199607)71:3<399::AID-JSFA609>3.0.CO;2-Q.

Grozdanovic, M. M., Ostojic, S., Aleksic, I., Andjelkovic, U., Petersen, A., \& Gavrovic-Jankulovic, M. (2014). Active actinidin retains function upon gastro-intestinal digestion and is more thermostable than the E-64-inhibited counterpart. Journal of the Science of Food and Agriculture, 94(14), 3046-3052. PMid:24633720. http://dx.doi. org/10.1002/jsfa.6656.

He, S., Simpson, B. K., Ngadi, M. O., \& Ma, Y. (2015). In vitro studies of the digestibility of lectin from black turtle bean (Phaseolus vulgaris). Food Chemistry, 173, 397-404. PMid:25466038. http:// dx.doi.org/10.1016/j.foodchem.2014.10.045.

Hiane, P. A., Baldasso, P. A., Marangoni, S., \& Macedo, M. L. R. (2006). Chemical and nutrition evaluation of kernels of bocaiuva, Acrocomia aculeata (Jacq.). Ciência e Tecnologia de Alimentos, 26(3), 683-689. http://dx.doi.org/10.1590/S0101-20612006000300031.

Hsiao, E. S., Lin, L. J., Li, F. Y., Wang, M. M., Liao, M. Y., \& Tzen, J. T. (2006). Gene families encoding isoforms of two major sesame seed storage proteins, $11 \mathrm{~S}$ globulin and $2 \mathrm{~S}$ albumin. Journal of Agricultural and Food Chemistry, 54(25), 9544-9550. PMid:17147444. http:// dx.doi.org/10.1021/jf061505x.

Kerr, W. E., Silva, F. R., \& Tchcarramae, B. (2007). Pequi (Caryocar brasiliense Camb.). Informações preliminares sobre um pequi sem espinhos no caroço. Revista Brasileira de Fruticultura, 29(1), 169-171. http://dx.doi.org/10.1590/S0100-29452007000100035.

Koppelman, J. S., Nieuwenhuizen, W. F., Gaspari, M., Knippels, L. M., Penninks, A. H., Knol, E. F., Hefle, S. L., \& de Jongh, H. H. (2005). Reversible Denaturation of Brazil Nut 2S Albumin (Ber e1) and Implication of Structural Destabilization on Digestion by Pepsin. Journal of Agricultural and Food Chemistry, 53(1), 123-131. PMid:15631518. http://dx.doi.org/10.1021/jf0491355.

Kumar, S., Sharma, A., Das, M., Jain, S. K., \& Dwivedi, P. D. (2014). Leucoagglutinating phytohemagglutinin: purification, characterization, proteolytic digestion and assessment for allergenicity potential in BALB/c mice. Immunopharmacology and Immunotoxicology, 36(2), 138-144. PMid:24548135. http://dx.doi.org/10.3109/08923 973.2014.884136.

Laemmli, U. K. (1970). Cleavage of strutural proteins during the assembly of the head of bacteriophage T4. Nature, 227(5259), 680685. PMid:5432063. http://dx.doi.org/10.1038/227680a0.

Lang, G. H., Kagiya, Y., \& Kitta, K. (2015). Multiplex comparison of the digestibility of allergenic and non-allergenic proteins in rice grains by in vitro digestion. Food Chemistry, 168, 606-614. PMid:25172754. http://dx.doi.org/10.1016/j.foodchem.2014.07.089.

Lima, A. J., Corrêa, A. D., Alves, A. P. C., Abreu, C. M. P., \& DantasBarros, A. M. (2008). Caracterização química do fruto da jaboticabeira (Myrciaria cauliflora Berg) e de suas frações. Alan, 58(4), 416-421. Retrieved from http://www.scielo.org.ve/pdf/alan/v58n4/art15.pdf

Lima, A., Silva, A. M. O., Trindade, R. A., Torres, R. P., \& MancianiFilho, J. (2007). Composição química e compostos bioativos na polpa e amêndoa do pequi (Caryocar brasiliense). Revista Brasileira de Fruticultura, 29(3), 695-698. http://dx.doi.org/10.1590/S010029452007000300052.

Lule, V. K., Garg, S., Pophaly, S. D., Hitesh, \& Tomar, S. K. (2015). Potential health benefits of lunasin: a multifaceted soy-derived bioactive peptide. Journal of Food Science, 80(3), R485-R494. PMid:25627564. http://dx.doi.org/10.1111/1750-3841.12786.

Mandal, S., Kundu, P., Roy, B., \& Mandal, R. K. (2002). Precursor of the inactive $2 S$ seed storage protein from the Indian mustard Brassica juncea is a novel trypsin inhibitor. Charaterization, posttranslational processing studies, and transgenic expression to develop insect-resistant plants. The Journal of Biological Chemistry, 277(40), 37161-37168. PMid:12147695. http://dx.doi.org/10.1074/ jbc.M205280200.

Maradini-Filho, A. M., Pirozi, M. R., Borges, J. T., Pinheiro Sant’ana, H. M., Chaves, J. B., \& Coimbra, J. S. (2017). Quinoa: nutritional, functional, and antinutritional aspects. Critical Reviews in Food Science and Nutrition, 57(8), 1618-1630. http://dx.doi.org/10.108 0/10408398.2014.1001811.

Moreno, F. J., Mellon, F. A., Wickham, M. S., Bottrill, A. R., \& Mills, E. N. (2005). Stability of the major allergen Brazil nut $2 S$ albumin (Ber e 1) to physiologically relevant in vitro gastrointestinal digestion. The FEBS Journal, 272(2), 341-352. PMid:15654873. http://dx.doi. org/10.1111/j.1742-4658.2004.04472.x.

Murtagh, G. J., Archer, D. B., Dumoulin, M., Ridout, S., Matthews, S., Arshad, S. H., \& Alcocer, M. J. (2003). In vitro stability and immunoreactivity of the native and recombinant plant food $2 S$ almumins Ber e 1 and SFA-8. Clinical and Experimental Allergy, 33(8), 1147-1152. PMid:12911791. http://dx.doi.org/10.1046/j.13652222.2003.01736.x.

Oliva, M. L., Ferreira, R. S., Ferreira, J. G., De Paula, C. A., Salas, C. E., \& Sampaio, M. U. (2011). Structural and functional properties of kunitz proteinase inhibitors from leguminosae: a mini review. Current Protein \& Peptide Science, 12(5), 348-357. PMid:21418019. http://dx.doi.org/10.2174/138920311796391061.

Oliveira, C. F., Marangoni, S., \& Macedo, M. L. (2014). The trypsin inhibitor from Entada acaciifolia seeds affects negatively the development of Mediterranean flour moth, Anagasta kuehniella. Pesticide Biochemistry and Physiology, 108, 74-79. PMid:24485318. http://dx.doi.org/10.1016/j.pestbp.2013.12.007.

Orruno, E., \& Morgan, M. R. A. (2011). Resistance of purified seed storage proteins from sesame (Sesamum indicum L.) to proteolytic digestive enzymes. Food Chemistry, 128(4), 923-929. http://dx.doi. org/10.1016/j.foodchem.2011.03.120.

Osborne, T. B. (1924). The vegetable proteins (2nd ed,. chap. III, pp. 13-21, Monographs in biochemistry). New York: Longman.

Pantoja-Uceda, D., Bruix, M., Giménez-Gallego, G., Rico, M., \& Santoro, J. (2003). Solution structure of RicC3, a 2S albumin storage protein from Ricinus communis. Biochemistry, 42(47), 13839-13847. PMid:14636051. http://dx.doi.org/10.1021/bi0352217.

Pesoti, A. R., Oliveira, B. M., Oliveira, A. C., Pompeu, D. G., Gonçalves, D. B., Marangoni, S., Silva, J. A., \& Granjeiro, P. A. (2015). Extraction, purification and characterization of inhibitor of trypsin from 
Chenopodium quinoa seeds. Food Science and Technology, 35(4), 588-597. http://dx.doi.org/10.1590/1678-457X.6655.

Pinto, J. R. R., Lenza, E., \& Pinto, A. S. (2009). Composição florística e estrutura da vegetação arbustivo-arbórea em um cerrado rupestre, Cocalzinho de Goiás, Goiás. Boletim dos Jardins Botânicos do Brasil, $32(1), 1-10$

Pompeu, D. G., Carvalho, A. S., Costa, O. F., Galdino, A. S., Gonçalves, D. B., Silva, J. A., \& Granjeiro, P. A. (2014). Anti-nutritional factors and "in vitro" digestibility of leaves of Pereskia aculeata Miller. Biochemistry and Biotechnology Reports, 3(1), 1-9. PMid:28626641. http://dx.doi.org/10.5433/2316-5200.2014v3n1p1.

Pompeu, D. G., Mattioli, M. A., Ribeiro, R. I. M. A., Gonçalves, D. B., Magalhães, J. T., Marangoni, S., Silva, J. A., \& Granjeiro, P. A. (2015). Purification, partial characterization and antimicrobial activity of Lectin from Chenopodium Quinoa seeds. Ciência e Tecnologia de Alimentos, 35(4), 696-703. http://dx.doi.org/10.1590/1678-457X.6823.

Pompeu, D. G., Pompeu, L. G., Tonelli, F. C. P., Santos, D. M., Silva, J. A., \& Granjeiro, P. A. (2016). Extraction, Purification, partial Characterization and Antimicrobial Activity of a Protease Inhibitor from Albizia niopoides seeds. International Journal of Advanced Scientific Research and Management, 1, 27-34.

Ribeiro, J. K. C. (2010). Novas propriedades do SKTI (inibidor de tripsina de soja): Inibição para elastase neutrofilica humana e efeitos no processo de injúria pulmonar aguda (Tese de Doutorado). Universidade Federal do Rio Grande do Norte, Natal.

Ruan, J. J., Zhou, M. L., Chen, H., \& Shao, J. S. (2011). Identification and characterization of a Trypsin inhibitor from Fagopyrum tataricum seeds. Applied Biochemistry and Biotechnology, 1-17. http://dx.doi. org/10.1007/s12010-011-9257-4. PMid:21544554.

Seena, S., \& Sridhar, K. R. (2004). Nutrient composition and biological evaluation of an unconventional legume, Canavalia cathartica of mangroves. International Journal of Food Sciences and Nutrition, 55(8), 615-625. PMid:16019306. http://dx.doi.org/10.1080/09637480500085622.

Sharon, N., \& Lis, H. (1995). Lectins-proteins with a sweet tooth: functions in cell recognition. Essays in Biochemistry, 30, 59-75. PMid:8822149.

Shewry, P. R., Napier, J. A., \& Tatham, A. S. (1995). Seed storage proteins: structures and biosynthesis. The Plant Cell, 7(7), 945-956. PMid:7640527. http://dx.doi.org/10.1105/tpc.7.7.945.

Silva, J. A., Damico, D. C. S., Baldasso, P. A., Mattioli, M. A., Winck, F. V., Fraceto, L. F., Novello, J. C., \& Marangoni, S. (2007). Isolation and biochemical characterization of galactoside biding lectin Bauhinia variegata candida (BvcL) Seeds. The Protein Journal, 26(3), 193-201. PMid:17203390. http://dx.doi.org/10.1007/s10930-006-9061-0.

Silva, J. A., Pompeu, D. G., Costa, O. F., Gonçalves, D. B., Spehar, C. R., Marangoni, S., \& Granjeiro, P. A. (2015a). The importance of heat against antinutritional factors from Chenopodium quinoa. Food Science and Technology, 35(1), 74-82. http://dx.doi.org/10.1590/1678457X.6427.

Silva, J. A., Pompeu, D. G., Smolka, M. B., Gozzo, F. C., Comar, M., Eberlin, M. N., Granjeiro, P. A., \& Marangoni, S. (2015b). Primary structure of a trypsin inhibitor (CTI-1) obtained from Copaifera langsdorffii seeds: a Kunitz trypsin-type inhibitor with two subunits and a single disulfide bridge. Journal of Biomolecular Techniques, 26(3), 90-102. PMid:26207098. http://dx.doi.org/10.7171/jbt.15-2603-002.

Singh, T. K., Øiseth, S. K., Lundin, L., \& Day, L. (2014). Influence of heat and shear induced protein aggregation on the in vitro digestion rate of whey proteins. Food \& Function, 5(11), 2686-2698. PMid:25205335. http://dx.doi.org/10.1039/C4FO00454J.

Sirvent, S., Palomares, O., Cuesta-Herranz, J., Villalba, M., \& Rodriguez, R. (2012). Analysis of the structural and immunological stability of $2 S$ albumin, nonspecific lipid transfer protein, and profilin allergens from mustard seeds. Journal of Agricultural and Food Chemistry, 60(23), 6011-6018. PMid:22594937. http://dx.doi.org/10.1021/jf300555h.

Van Damme, E. J. (2014). History of plant lectin research. Methods in Molecular Biology, 1200, 3-13. PMid:25117220. http://dx.doi. org/10.1007/978-1-4939-1292-6_1.

Vasconcelos, I. M., \& Oliveira, J. T. (2004). Antinutritional properties of plant lectins. Toxicon, 44(44), 385-403. PMid:15302522. http:// dx.doi.org/10.1016/j.toxicon.2004.05.005.

Vissers, Y. M., Blanc, F., Skov, P. S., Johnson, P. E., Rigby, N. M., Przybylski-Nicaise, L., Bernard, H., Wal, J. M., Ballmer-Weber, B., Zuidmeer-Jongejan, L., Szépfalusi, Z., Ruinemans-Koerts, J., Jansen, A. P., Savelkoul, H. F., Wichers, H. J., Mackie, A. R., Mills, C. E., \& Adel-Patient, K. (2011). Effect of heating and glycation on the allergenicity of $2 \mathrm{~S}$ albumins (Ara h 2/6) from Peanut. PLoS One, 8(44), 1-9. http://dx.doi.org/10.1371/journal.pone.0023998. PMid:21901150.

World Health Organization - WHO. (2007). Protein and amino acid requirements in human nutrition (WHO Technical Report Series, 935). Geneva: WHO. 